\title{
Effect of dietary supplementation with selenium-enriched yeast or sodium selenite on ruminal enzyme activities and blood chemistry in sheep
}

\author{
Zita Faixová ${ }^{1}$, Elena Piešová ${ }^{1}, Z_{\text {Zzana Maková }}{ }^{,}$Klaudia Čobanová ${ }^{2}$ Štefan Faix ${ }^{2}$ \\ ${ }^{1}$ University of Veterinary Medicine and Pharmacy in Košice, Institute of Pathological Physiology, \\ Košice, Slovak Republic \\ ${ }^{2}$ Slovak Academy of Sciences, Institute of Animal Physiology, Košice, Slovak Republic
}

\author{
Received April 18, 2015 \\ Accepted May 2, 2016
}

\begin{abstract}
The experiment was conducted to evaluate the effect of feeding a diet supplemented with different forms of selenium on the rumen fluid, blood and serum enzyme activity and osmotic fragility of red blood cells in sheep. The experiment was carried out on 18 sheep of the Valashka breed at the age of 18 months, divided into 3 groups. The first group was given basal diet (BD) with a Se content of $0.17 \mathrm{mg} / \mathrm{kg}$ of dry matter (DM). The second group received BD supplemented with $0.4 \mathrm{mg} \mathrm{Se} / \mathrm{kg}$ of (DM) in the form of sodium selenite. The third group received BD supplemented with $0.4 \mathrm{mg} \mathrm{Se} / \mathrm{kg}$ of (DM) in the form of Se-yeast extract. Duration of the trial was 12 weeks. Selenium concentration in blood and total rumen fluid were elevated in both supplemented groups with the highest values in Se-yeast-treated sheep. Blood glutathione peroxidase (GPx) activity was significantly increased, regardless of the source of selenium. Osmotic resistance of red blood cells was not affected by selenium supplementation. The results indicate that feeding a diet supplemented with selenium from Se-yeast or selenite improved selenium status in blood and total rumen fluid. Selenium from sodium selenite was as effective as selenium from Se-yeast in the availability of selenium for the blood GPx activity. The effect of selenium supplementation on the ruminal enzyme activity depends on the selenium form; GGT and GDH were significantly higher in the Se-yeast supplement group, AST and ALP were significantly higher in the selenite supplement group.
\end{abstract}

Rumen, blood enzymes, ruminant

Selenium is an essential trace element which plays an important role in the antioxidative, reproductive, endocrine and immune systems of species.

In most European Union countries the natural Se content in feed is only $0.03-0.12 \mathrm{mg} / \mathrm{kg}$ of dry matter (Pappas et al. 2008). The intake of such feeds can result in serious Se deficiencies and health problems especially in young growing and highly producing animals.

For this reason commercial animal feeds are routinely supplemented with various $\mathrm{Se}$ sources up to the maximum European Union authorized total Se content of $0.5 \mathrm{mg} / \mathrm{kg}$ of feed.

Currently, sodium selenite $\left(\mathrm{Na}_{2} \mathrm{SeO}_{3}\right)$ and sodium selenate $\left(\mathrm{Na}_{2} \mathrm{SeO}_{4}\right)$ as inorganic and selenium-enriched yeast (Se-yeast) as organic Se are principal selenium supplements of animal feed.

It is established that selenocompounds from dietary inorganic and organic Se sources follow different metabolic pathways (Q in et al. 2007; Wang et al. 2009). Intestinal absorption of $\mathrm{Se}$ is much lower in ruminants than in nonruminants. For selenite, the absorption is $79 \%$ and $80 \%$ in poultry and swine, respectively, whereas only $29 \%$ in sheep. For selenomethionine and selenate the absorption is higher than $90 \%$ in monogastrics and poultry. Low absorption of selenium in ruminants is believed to result from reduction of dietary selenium (selenite and selenate) to unsoluble forms such as elemental selenium or selenides in the rumen environment (Mehdi et al. 2013).

Address for correspondence:

Zita Faixová

Institute of Pathological Physiology

University of Veterinary Medicine and Pharmacy in Košice

Komenského 73, 04181 Košice, Slovak Republic

Phone: +421915 984704

E-mail: zita.faixova@uvlf.sk

http://actavet.vfu.cz/ 
There are several methods of evaluation of the selenium status in species. It can be measured in plasma, serum, whole blood, milk, rumen fluid or in tissues. These methods are direct. Selenium may also be measured by an indirect method, assessing the glutathione peroxidase (GPx) activity in erythrocytes. Glutathione peroxidases catalyze the reduction of lipid and hydrogen peroxides to hydroxides via the oxidation and subsequent reduction of selenocysteine (SeCys), which is the active center of the enzyme (Arteel and Sies 2001).

There are reports that whole blood GPx was significantly higher in ruminants offered Seyeast compared to those that received sodium selenite (Juniper et al. 2008). Similar results were reported by Qin et al. (2007). However, Van Ryssen et al. (1989) and Gunter et al. (2003) found no differences in the GPx activity in whole blood of animals given organic or inorganic selenium.

Previous findings (Mihaliková et al. 2005; Panev et al. 2013) have shown that rumen microbial population is capable of incorporating Se into their cells. Several studies have dealt with the effects of various Se forms on the rumen enzyme activity.

It has been reported that supplementation with sodium selenite together with vitamin E increased production of fatty acids and number of protozoa (Naziroglu et al. 1997). Our previous results showed an increase of the glutamate dehydrogenase enzyme in the ruminal fluid of lambs fed Se-yeast enriched diet with $0.3 \mathrm{mg} \mathrm{Se} / \mathrm{kg}$ of DM compared to the group given basal diet (Faixová et al. 2007). Mihaliková et al. (2005) reported that selenomethionine has a protective effect on the growth of some protozoa species in young ruminants.

On the other hand, other authors did not find any significant changes after in vitro application of selenium (Feasenhaser 2005). It has been also reported that higher Se concentration can have a harmful effect on ruminal microflora and/or ruminal mucosa. The increase in enzymes of ruminal fluid results from damaged ruminal bacteria and/or mucosa in the rumen. In addition, the chemical form of Se in the supplement did not affect ruminal fermentation indicators in dependence on different doses of Se contained in feeding rations. However, a negative effect of a sudden start of feeding high contents of organically bound Se on the infusoria count was reported, which was accompanied by the increase of GMT, LDH and AST enzymes activity in ruminal fluid (Panev et al. 2013).

Several studies have shown that selenium deficiency leads to increased oxidative degradation of compounds susceptible to oxidation. Polyunsaturated fatty acids (PUFA) in biological membranes are highly susceptible to peroxidation. They play an important role in membrane properties such as structure, fluidity, permeability and activities of enzymes located within membranes. Moreover, autooxidative degradation products can damage membranes such as erythrocyte membranes.

Our previous experiment showed that the total erythrocyte count was significantly higher in Se-yeast supplemented lambs than in the control group, and the total white blood cell count was significantly higher in the control group than in the Se-yeast supplemented group (Faixová et al. 2007). According to literature, selenium is essential in regulating haematopoiesis by differentiation of erythroid progenitors of C57/BL6 mice (Kaushal et al. 2011).

The present study evaluates the effect of forms of supplemented selenium on selected indicators of the ruminal fluid and blood in sheep. The aim was to find whether selenium availability of the organic compound is higher compared to the inorganic one and whether higher concentration of selenium in one or the other form affects the rumen enzyme activity and fragility of red blood cells in sheep.

\section{Materials and Methods}

The experiment was carried out on 18 sheep of the Valashka breed at the age of 18 months, divided into three groups of six animals and kept on diets that differed in the form of selenium supplement. 
Animals were housed in individual pens with free access to fresh potable water and specially prepared trace mineral lick without Se, and were fed diets used for 12 weeks before sampling. The sheep weighed $40 \mathrm{~kg}$ at the end of experiment. The composition of mineral lick $(\mathrm{g} / \mathrm{kg})$ without Se: calcium $(\mathrm{Ca}) 16.2$, natrium (Na) 316, magnesium $(\mathrm{Mg}) 32$, copper $(\mathrm{Cu})$ 0.7, manganese $(\mathrm{Mn})$ 2.5, zinc $(\mathrm{Zn}) 3.1$, cobalt $(\mathrm{Co})$ 0.06, and iodine (I) 0.02 .

The first group (control) was given a basal diet (BD) containing (g/day per animal): $1500 \mathrm{~g}$ grass hay and $500 \mathrm{~g}$ ground barley with the Se content of $0.17 \mathrm{mg} / \mathrm{kg}$ of dry matter (DM) coming from the natural occurrence of Se in the dietary component only. The second group received basal diet supplemented with $0.4 \mathrm{mg} \mathrm{Se} / \mathrm{kg}$ of $\mathrm{DM}$ of inorganic selenium in the form of sodium selenite $\left(\mathrm{Na}_{2} \mathrm{SeO}_{3}\right)$, resulting in $0.53 \mathrm{mg} \mathrm{Se} / \mathrm{kg}$ of DM. Sodium selenite with 99\% purity (Sigma-Aldrich, USA) was dissolved in water and top dressed on ground barley during each feeding. The third group received basal diet supplemented with $0.4 \mathrm{mg} \mathrm{Se} / \mathrm{kg}$ of DM in the form of Se-yeast extract (Se-Plex, Alltech Inc., USA), resulting in $0.46 \mathrm{mg} \mathrm{Se} / \mathrm{kg}$ of DM (Table 1).

Table 1. The experimental design and selenium concentration in the experimental groups.

\begin{tabular}{lccc}
\hline Group/treatment & $\begin{array}{c}\text { Group 1 } \\
\text { Basal diet }\end{array}$ & Group 2 & Group 3 \\
\hline Selenium source & & Sodium selenite (SS) & Se-yeast \\
\hline $\begin{array}{l}\text { Selenium concentration } \\
\text { Additive }\left(\mathrm{mg} \cdot \mathrm{kg}^{-1} \text { feed) }\right.\end{array}$ & 0.0 & 0.4 & 0.4 \\
$\quad$ Analysed $\left(\mathrm{mg} \cdot \mathrm{kg}^{-1}\right.$ dry matter) & 0.17 & 0.53 & 0.46 \\
\hline
\end{tabular}

\section{Selenized yeast was directly mixed with ground barley}

The major Se-compound of selenized yeast is selenomethionine (SeMet). The preparations of selenized yeast are reported to contain $54-74 \%$ of total Se in the form of SeMet, depending on the extraction efficiency of the techniques used by the analytical laboratories (Rayman 2004).

Animals were fed the diets divided into two portions offered at $7.00 \mathrm{~h}$ and $15.00 \mathrm{~h}$. The daily ration for all treatments was prepared fresh daily and differed only in the form of selenium supplement. There were no dietary refusals and the feed was completely consumed by animals.

\section{Blood collection}

Blood samples were collected from each sheep from vena jugularis into heparinized and non-heparinized tubes. Blood collected in non-heparinized tubes was centrifuged at 2,000 $\times \mathrm{g}$ for $20 \mathrm{~min}$ and the serum was decanted and stored at $-65^{\circ} \mathrm{C}$ until analysis.

Activity of blood glutathione peroxidase (GPx, EC 1.11.1.9) was determined using the metod of Paglia and Valentine (1967) with a RANSEL kit (Randox, United Kingdom). Erythrocyte osmotic fragility test was performed by the method of Coles (1986).

Ruminal fluid collection

Ruminal fluid was obtained by stomach tube $2 \mathrm{~h}$ after the morning feeding. Duplicate samples of the ruminal fluid were strained through four layers of cheesecloth with $30 \mathrm{~min}$ of collection.

The ruminal enzyme activities of alanine aminotransferase (ALT, EC 2.6.1.2) and aspartate aminotransferase (AST, EC 2.6.1.1) were measured by the method of Reitman and Frankel (1957) and glutamate dehydrogenase (GDH, EC 1.4.1.3) was determined by the method of Schmidt and Schmidt (1983) with commercial kits (Randox, Ardmore, UK). The activities of gamma-glutamyl transferase (GGT, EC 2.3.2.1) was determined according to Dimov and Kulhanek (1967) and alkaline phosphatase (ALP, EC 3.1.3.1) was measured using the method of Schmidt et al. (1990) with commercial kits (Pliva-Lachema, Brno, Czech Republic).

\section{Selenium determination}

Selenium contents in the feed components, blood, and rumen fluid were analysed flurometrically according to the method of Rodriguez et al. (1994).

\section{Statistical analysis}

The results are expressed as means \pm standard errors of the means (SEM). Statistical analysis was done by one-way analysis of variance (ANOVA) with Tukey's post hoc multiple comparison test (GraphPad Software, La Jolla, USA).

The experiments were carried out in accordance with the established standards for the use of experimental animals. The protocol was approved by the local ethics and scientific authorities. 


\section{Results}

Selenium concentration in the rumen fluid and selenium level in blood (Fig. 1) and glutathione peroxidase (GPx) activity in blood (Table 2) were significantly increased compared to the control group. Between experimental groups, the selenium concentration in blood and rumen fluid was higher in the Se-yeast group. There were no differences between groups in the osmotic resistance of red blood cells (Table 2).

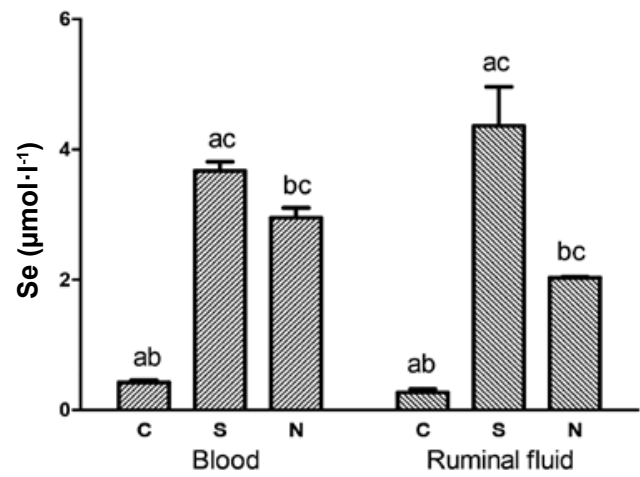

Fig. 1. Selenium concentration in blood and ruminal fluid in control and selenium supplemented groups Significant differences between columns of respective indicators are indicated by the same letter, $P<0.05$, results are expressed as the mean of six determinations \pm SEM.

$\mathrm{C}$ - control group, $\mathrm{S}$ - selenized yeast, $\mathrm{N}$ - sodium selenite

The source of selenium fed to sheep differently affected the alkaline phosphatase (ALP) activity in rumen fluid; the Se-yeast supplemented diet significantly decreased, whereas the $\mathrm{Na}_{2} \mathrm{SeO}_{3}$-supplemented diet significantly increased the enzyme activity.

Activities of gamma-glutamyl transferase (GGT) and glutamate dehydrogenase were significantly increased in the rumen fluid of sheep supplemented with Se-yeast and the aspartate amino transferase activity was significantly higher in sheep fed the diet supplemented with $\mathrm{Na}_{2} \mathrm{SeO}_{3}$. Alanine amino transferase activity in the rumen fluid was not affected by the treatment (Table 3 ).

Table 2. The effect of supplemental selenium on the osmotic resistance of red blood cells and the glutathione peroxidase activity in blood.

\begin{tabular}{lccr}
\hline & Control (basal diet) & $\begin{array}{c}\text { Selenized yeast } \\
\text { (Sel-Plex) }\end{array}$ & $\mathrm{Na}_{2} \mathrm{SO}_{3}$ \\
\hline $\begin{array}{c}\text { The osmotic resistance of RBCs } \\
\text { a) minimal }\end{array}$ & $0.59 \pm 0.015$ & $0.63 \pm 0.10$ & $0.64 \pm 0.015$ \\
b) maximal & $0.44 \pm 0.015$ & $0.46 \pm 0.016$ & $0.50 \pm 0.022$
\end{tabular}

Significant differences within a row are indicated by the same superscript letter, $P<0.05$. Results are expressed as mean of six determinations \pm SEM.

$\mathrm{RBC}$ - red blood cell, GPx - glutathione peroxidase

\section{Rumen}

\section{Discussion}

Selenium concentration in the total rumen fluid was significantly higher in sheep supplemented with selenium from the organic (Se-yeast) or the inorganic $\left(\mathrm{Na}_{2} \mathrm{SeO}_{3}\right)$ source in comparison with the control group of sheep. Comparing Se-supplemented groups, the 
Table 3. The effect of supplemental selenium on the enzyme activity and selenium content in the ruminal fluid of sheep.

\begin{tabular}{llcl}
\hline Indicator & $\begin{array}{c}\text { Control } \\
(\text { basal diet })\end{array}$ & $\begin{array}{c}\text { Selenized yeast } \\
(\text { Sel-Plex })\end{array}$ & $\mathrm{Na}_{2} \mathrm{SO}_{3}$ \\
\hline GGT $\left(\mu \mathrm{kat} \cdot l^{-1}\right)$ & $1.26 \pm 0.046^{\mathrm{a}}$ & $3.48 \pm 0.210^{\mathrm{ab}}$ & $1.77 \pm 0.124^{\mathrm{b}}$ \\
ALT $\left(\mu \mathrm{kat} \cdot 1^{-1}\right)$ & $1.57 \pm 0.10$ & $1.84 \pm 0.03$ & $1.79 \pm 0.04$ \\
AST $\left(\mu \mathrm{kat} \cdot l^{-1}\right)$ & $2.76 \pm 0.060^{\mathrm{a}}$ & $2.735 \pm 0.101^{\mathrm{b}}$ & $3.33 \pm 0.128^{\mathrm{ab}}$ \\
$\mathrm{GDH}\left(\mu \mathrm{kat} \cdot 1^{-1}\right)$ & $0.25 \pm 0.012^{\mathrm{a}}$ & $0.38 \pm 0.015^{\mathrm{ab}}$ & $0.29 \pm 0.014^{\mathrm{b}}$ \\
$\mathrm{ALP}\left(\mu \mathrm{kat} \cdot l^{-1}\right)$ & $1.37 \pm 0.067^{\mathrm{ab}}$ & $0.95 \pm 0.061^{\mathrm{bc}}$ & $2.27 \pm 0.087^{\mathrm{ac}}$ \\
\hline
\end{tabular}

Significant differences within a row are indicated by the same superscript letter, $P<0.05$, results are expressed as the mean of six determinations \pm SEM.

GGT - gamma-glutamyltransferase; ALT - alanine aminotransferase; AST - aspartate amino transferase; GDH - glutamate dehydrogenase; ALP - alkaline phosphatase

selenium concentration in the rumen fluid was significantly higher in the Se-yeast group.

Selenium added to the feeding ration is not fully utilized by the animal's organism, as its significant part is absorbed and metabolized by ruminal bacteria, thus the highest selenium concentrations are found in ruminal biomass, whereas the lowest are in the ruminal fluid (Serra et al. 1994; Panev et al. 2013).

In ruminats, inorganic Se compounds are partly reduced by ruminal microbes to unabsorbable elemental selenium resulting in a lower Se apparent absorption. Selenoamino acids are subject to ruminal microbial degradation also decreasing apparent selenium absorption from the digestive tract (Van Ryssen and Schroeder 2003).

It is well established that dietary composition influences the microbial population in the rumen which in turn can modify the availability of dietary Se for absorption and also its subsequent retention in the body of ruminants.

Rumen microorganisms have been shown to incorporate Se from both inorganic and organic forms into their own protein and into the microbial cell wall components (Koenig et al. 1997).

There is some evidence indicating that Se metabolism in the rumen is dependent on the prevalence of particular species of rumen bacteria. It has been demonstrated that pure cultures of Selenomonas ruminantium and Butyrivibrio fibrisolvens incorporated Se into selenoamino acids whereas Bacteroides ruminicola reduced seleno-compounds into elemental Se only (Hudman and Glenn 1985).

It has been suggested that the release of selenomethionine from Se-yeast proteins in the digestive tract should correspond to the digestion of other total proteins in ruminants. Factors affecting the ruminal degradation of proteins such as heat processing of feeds can therefore modify the fate of Se compounds in the rumen and affect the proportion of Se amounts available for microbial reduction or incorporation into their own proteins and enable Se-containing compounds to escape rumen microbial fermentation (Van Ryssen and Schroeder 2003). Mihaliková et al. (2005) reported that Se supplementation showed protective effects against the development of some ciliate species in young ruminants. The inclusion of Se-yeast into sheep's feed had a more pronounced effect on the population of Ophryoscolex and Diploplastron than feed supplementation with an equivalent amount of sodium selenite. The most sensitive rumen ciliate genera to Se dietary intake appear to be Ophryoscolex which did not even occur in sheep with deficient Se intake.

The protective effect of Se on the rumen microflora was demonstrated in sheep fed a basal diet (BD) containing $0.07 \mathrm{mg} \mathrm{Se} / \mathrm{kg}$ of DM, while the experimental group was supplemented with Se at a dose of $0.3 \mathrm{mg} / \mathrm{kg}$ of dry matter in the form of sodium selenite. Se level and glutathione peroxidase (GPx) activity was significantly higher and malondialdehyde (MDA) concentration was significantly lower in bacterial and protozoal fractions of the rumen fluid in Se-supplemented animals, which confirms the ability of rumen micro- 
flora to accumulate dietary Se, and the effectiveness of rumen microflora to utilize Se from sodium selenite and to use it for synthesis of the seleno aminoacid Se-cysteine. Se-amino acids incorporated into microbial proteins are highly available sources of selenium for their absorption in the lower part of the gastrointestinal tract (Čobanová - Boldižárová et al. 2008).

Se-yeast supplemented diet significantly affected rumen fluid enzyme activity and increased the activity of enzymes involved in nitrogen metabolism in rumen (e.g., GGT and GDH). Our results show that the effect of selenium supplementation on ruminal enzyme activity depends on the selenium form. Gamma-glutamyl transferase and glutamate dehydrogenase were significantly higher in the Se-yeast supplemented group, and aspartate amino transferase and alkaline phosphatase were significantly higher in the selenite supplemented one.

There are several reports available on the relationship between dietary Se and rumen fermentation. Kim et al. (1997) found that Se (as SeMet, $2 \mathrm{mg} / \mathrm{kg}$ ) can stimulate in vitro fermentative activity of rumen microoorganisms compared to the addition of elementary selenium or sodium selenite, or no selenium supplementation. Naziroglu et al. (1997) reported an increase of total volatile fatty acids and propionate production, the total counts of protozoa of the ruminal fluid of lambs supplemented by $0.3 \mathrm{mg} \mathrm{Se} / \mathrm{kg} \operatorname{diet}\left(\mathrm{Na}_{2} \mathrm{SeO}_{3}\right)$ in vitro. The ammonia nitrogen content was not affected by the Se-treated diet. Similarly, Liu et al. (2007) reported reduction of ratio of acetate to propionate due to an increase in propionate production when steers were fed 300 and $600 \mathrm{mg}$ Se-yeast $/ \mathrm{kg}$ dietary DM.

Later Xun et al. (2012) reported that ruminal $\mathrm{pH}$, ammonia $\mathrm{N}$ concentration, molar proportion of propionate, and ratio of acetate to propionate were decreased $(P<0.01)$ and total VFA concentration were increased with $4 \mathrm{~g}$ nano-Se $(4 \mathrm{mg} \mathrm{Se} / \mathrm{kg}$ of dry matter) and $4 \mathrm{~g}$ Se-yeast supplementation (provide $4 \mathrm{mg} \mathrm{Se} / \mathrm{kg}$ of DM) in ruminally cannulated sheep. This agrees with the results of Shi et al. (2011) who obtained higher VFA concentration and lower $\mathrm{pH}$ in the sheep fed with the basal diet supplemented with $3 \mathrm{~g}$ of nano-Se (provide $3 \mathrm{mg} \mathrm{Se} / \mathrm{kg}$ of DM) in sheep. Similar results were also found in cows (Wang et al. 2009).

However, Serra et al. (1994) showed that the concentration of total volatile fatty acids VFA and propionate decreased slightly by administration $0.2 \mathrm{mg} \mathrm{Se}\left(\mathrm{Na}_{2} \mathrm{SeO}_{3}\right.$ or $\left.\mathrm{Na}_{2} \mathrm{SO}_{4}\right)$ per kg of DM in sheep. Dutt and Chhabra (2008) report that supplementation of $0.5 \mathrm{ppm}$ selenium either in the inorganic or the organic form had no significant effect on the nutrient intake, rumen microbial population, and protein synthesis in cattle and buffaloes.

The effect of selenium supplementation on ruminal enzyme activity in the present study may be explained as follows. We did not evaluate other indicators of rumen fermentation or feed digestibility so we can only speculate on the hypothesis.

According to literature reports, supplementation of selenium in organic (Se-yeast) in cows (Wang et al. 2009) or Se-yeast and nano-Se in sheep (Xun et al. 2012) in the diet switched the rumen fermentation pattern from acetate to propionate and decreased the ammonia $\mathrm{N}$ concentration, which suggested that selenium supplemenation in diet particularly increased microbial activity in propionate production. In addition, Xun et al. (2012) reported a decrease of concentration of volatile fatty acids with high seleniumyeast versus medium selenium- yeast, indicating the increase of Se-yeast dose from $0.3 \mathrm{mg} \mathrm{Se} / \mathrm{kg}$ of dietary DM to $0.45 \mathrm{mg} \mathrm{Se} / \mathrm{kg}$ of dietary DM was not beneficial to further increase of feed fermentation in the rumen.

It can be suggested that stimulation of microbial activity by Se-yeast may be in dosedependent.

In addition, Panev et al. (2013) studied the effects of various doses of Se on selected variables of the ruminal fluid and blood in sheep. They reported that the form of supplemented Se did not have a significant effect on ruminal fermentation indicators $(\mathrm{pH}$, total acidity, volatile fatty acids, and ammonia) except for the negative effect of the 
sudden start of feeding high contents of organically bound Se on the infusoria count, which was accompanied by an increase of gamma-glutamyl transferase, lactate dehydrogenase, and aspartate amino transferase activity in the ruminal fluid. It can be suggested that enhanced growth of the ruminal microbial population by Se-yeast could increase the ammonia nitrogen consumption and increase the activity of enzymes of nitrogen metabolism in the rumen fluid such as glutamate dehydrogenase and gamma-glutamyl transferase found in the present study. An increase of the glutamate dehydrogenase enzyme in the ruminal fluid was reported in our previous study on lambs fed a Se-yeast enriched diet with $0.3 \mathrm{mg}$ $\mathrm{Se} / \mathrm{kg}$ diet DM compared to the group given basal diet (Faixova et al. 2007).

\section{Selenium in blood}

Blood Se concentration was significantly higher in sheep supplemented with selenium from the organic (Se-yeast) or inorganic $\left(\mathrm{Na}_{2} \mathrm{SeO}_{3}\right)$ source in comparison with the control group of sheep. However, between experimental groups the Se concentration in blood was significantly higher in the Se-yeast group.

This finding is in agreement with the study by Hall et al. (2012) who studied the effects of the Se source (inorganic vs. organic) and supplementation rate (the Food and Drug Administration, FDA vs. supranutritional rates) on whole - blood and serum - Se concentrations in mature ewes. Their results showed that the dose range whereby $\mathrm{Se}$ supplementation increased blood Se concentrations was more limited for the inorganic $\mathrm{Na}$ - selenite than for the organic Se-yeast. The smallest rate (FDA recommended quantity) of organic Se supplementation was equally effective as the supranutritional rates of Naselenite supplementation in increasing whole blood Se concentrations, demonstrating greater oral bioavailability of organic Se.

Rock et al. (2001) reported that Se supplementation in pregnant ewes either by sodium selenite or selenized yeast significantly increased the Se concentration in whole blood and serum, increased the activity of glutathione peroxidase (GPx) in both the pregnant ewes and the lambs of ewes given Se. When the two Se supplements were compared, lambs of the ewes which were fed the Se-yeast had higher $(P<0.001)$ concentrations of Se and activities of $\operatorname{GPx}(P<0.05)$ in blood than lambs of the ewes fed selenite.

Similarly, there were significant differences $(P<0.05)$ between the two Se sources in whole blood Se concentration, with values being higher in the Se-yeast supplemented animals $(0.30 \mathrm{mg} \mathrm{Se} / \mathrm{kg}$ of DM) compared to those that received a comparable dose of sodium selenite, indicating a better uptake and incorporation of Se derived from Se-yeast in beef cattle (Juniper et al. 2008). These observations are in line with those of Van Ryssen et al. (1989) in sheep, Falkowska et al. (2000) and Gunter et al. (2003) in cows, Ortman and Pehrson (1999) in dairy cows and Pechova et al. (2012) in goats, who reported higher whole blood Se concentrations in animals supplemented with organic Se compared to those administered diets of a comparable Se content where sodium selenite was the source of supplementary Se.

On the other hand, Pavlata et al. (2011) reported that Se supplementation in goats either by sodium selenite or the new organically bound (lactate-protein complex) form of selenium for three months significantly increased the concentration of selenium in blood and no differences were found regarding the source of Se. However, the GPx activity increased much faster with selenite, which therefore appears to be a more biologically available form of Se for the synthesis of biologically active selenoproteins.

\section{Glutathione peroxidase activity in blood}

Our results showed that the activity of GPx in blood was significantly elevated in both groups supplemented with sodium selenite or Se-yeast compared to the animals fed the control diet. There were no differences between the animals given inorganic or organic 
selenium. Similar results were reported by other authors in sheep (Van Ryssen et al. 1989; Gunter et al. 2003).

In contrast to our results, other authors reported that whole blood GPx was significantly higher in beef cattle offered Se-yeast compared to those that received a comparable dose of sodium selenite (Juniper et al. 2008). Qin et al. (2007) also showed a significantly higher whole blood selenium concentration and GPx activities in lambs fed Se-yeast enriched diet $(0.10 \mathrm{mg} / \mathrm{kg}$ of diet) compared to lambs fed similar concentrations of sodium selenite. The differences in results obtained by the researchers might be explained by the fact that although whole blood Se concentration is closely correlated with the GPx activity (Brigelius-Flohe et al. 1994), there is evidence that the percentage of Se in erythrocytes associated with GPx may vary depending on the Se source (Belstein and Whanger 1986; Van Ryssen et al. 1989).

\section{Osmotic fragility of red blood cells}

Erythrocyte osmotic fragility was not significantly affected by selenium supplementation.

In agreement with the current study, Saini et al. (2007) reported no effect in the membrane permeability and physicochemical alteration of erythrocytes in the presence of Se and vitamin $\mathrm{E}$ in goats.

In contrast, fragility of erythrocyte membranes was significantly decreased in $\mathrm{SeO}_{2}$-treated rats compared to control (Chen and Lin 2000). In addition, Li et al. (1990) reported that the Se concentration in blood of children living in the endemic areas of the Kaschin-Beck disease (KBD) was lower than that in the non-endemic areas. Moreover, the fragility of erythrocytes was increased, indicating membrane defects and membrane damage in KBD. Recently Kaushal et al. (2011) suggested that Se is essential in regulating haemopoiesis by differentiation of erythroid progenitors in C57/BL6 mice.

These discrepancies may be due to differences in species bioavailability of Se (Pavlata et al. 2001), the amount and chemical form of supplemental Se (Pavlata et al. 2005) and erythrocyte osmotic fragility between species.

In conclusion, feeding diets supplemented with selenium from organic or inorganic sources significantly increased the Se concentrations in the total rumen fluid and blood, and the blood GPx activity. Comparing comparable doses from different Se sources, Se concentration in the blood and total rumen fluid was higher in the Se-yeast group. However, there were no differences in the blood GPx activity between the Se sources, indicating that Se from sodium selenite was as effective as Se from Se-yeast in the availability for the blood GPx activity of sheep. The effect of Se supplementation on the ruminal enzyme activity depends on the Se form - GGT and GDH were significantly higher in the Se-yeast supplemented group, and AST and ALP were significantly higher in the selenite supplemented group. These prelimitary results contribute to existing knowledge about the effects of Se supplementation on the ruminal enzyme activity in sheep. Further studies are needed in order to clarify the mechanisms of various Se forms on the rumen fermentation processes.

\section{Acknowledgment}

This work was supported by the VEGA grant n.1/0374/14.

\section{References}

Arteel GE, Sies H 2001: The biochemistry of selenium and glutathione system. Environ Toxicol Pharmacol 10: 153-158

Belstein M, Whanger PD. 1986: Deposition of dietary organic and inorganic selenium in rat erythrocyte proteins. J Nutr 116: 1701-1710

Brigelius-Flohe R, Aumann K-D, Blocker H, Gross G, Kiess M, Kloppel K-D, Maiorino M, Roveri A, Schuckelt R, Usini F, Wingender E, Flohe L 1994: Phospholipid-hydroperoxide glutathione peroxidase. Genomic DNA, cDNA, and reduced amino acid sequence. J Biol Chem 269: 7342-7348 
Coles EH 1986: Veterinary Clinical Pathology. $4^{\text {th }}$ edn. WB Saunder Company, Philadelphia, $437 \mathrm{p}$.

Čobanová-Boldižárová K, Grešáková L', Faix S, Petrovič V, Leng L': Selenium in sheep nutrition. Current advances in selenium research and application. Wageningen: Wageningen Academic Publishers, 2008, pp 209-220

Dimov DM, Kulhánek V 1967: Comparison of four methods for the estimation of gamma-glutamyl transpeptidase activity in biological fluids. Clin Chim Acta 2: 271-277

Dutt C, Chhabra A 2008: Effect of inorganic selenium supplementation on nutrient intake and rumen microbial population and protein content in cattle and buffaloes. Indian J Anim Sci 78: 548-763

Faixová Z, Faix Š, Leng L', Váczi P, Maková Z, Szabóová R 2007: Haematological, blood and rumen chemistry changes in lambs following supplementation with Se-yeast. Act Vet Brno 76: 3-8

Falkowska A, Minakowski D, Tywonczuk J 2000: The effect of supplementing rations with selenium and vitamin E on biochemical parameters in blood and performance of cows in the early stages of lactation. J Anim and Feed Sci 9: 271-283

Feasenhiser D 2005: The effects of organic selenium on rumen volatile fatty acids production in continuous culture. Cantaurus 13: 10-13

Gunter SA, Beck PA, Phillips JM 2003: Effects of supplementary selenium source on the performance of blood measurements in beef cows and their calves. J Anim Sci 81: 856-864

Hall JA, Saunt RJ, Bobe G, Stewart WC, Vorahek WR, Mosher WD, Nichols T, Forsberg NE, Pirelli GJ 2012: Organic and inorganic selenium: I. Oral bioavailability in ewes. J Anim Sci 90: 568-576

Hudman JF, Glenn AR 1985: Selenium uptake by Butyrivibrio fibrosolvens and Bacteroides ruminicola. FEMS Microbiology Letters 27: 215-220

Chen CY, Lin TH 2000: Effects of selenium dioxide on blood and femoral bone marrow of rats. J Toxicol Environ Health A 59: 553-560

Juniper DT, Phillipps RH, Ramos-Morales E, Bertin G 2008: Effect of dietary supplementation with seleniumenriched yeast or sodium selenite on selenium tissue distribution and meat quality in beef cattle. J Anim Sci 86: 3100-3109

Kaushal N, Hegde S, Lumadue J, Pauson RF, Prabhu KS 2011: The regulation of erythropoiesis in mice. Antioxid Redox Signal 14: 1403-1412

Kim J, Van Soest PJ, Combs GF, Jr 1997: Studies on the effects of selenium on rumen microbial fermentation in vitro. Biol Trace Elem Res 56: 203-213

Li FS, Duan UJ, YAn SJ, Guan JY, Zou LM, Wei FC, Mong LY, Li L, Li SY 1990: Presenile (early ageing) changes in tissues of Kaschin-Beck disease and its pathogenic significance. Mech Ageing Dev 54: 103-120

Liu Q, Wang C, Huang YX, Miao CH, Gao DH 2007: Effects of selenium-yeast on nutrient metabolism and serum physicochemical parameters in Simmental steer. Chinese J Anim Nutr 19: 379-385

Mehdi Y, Hornick J-L, Istasse L, Dufranse I 2013: Selenium in the environment, metabolism and involvment in body functions. Molecules 18: 3292-331

Mihaliková K, Grešáková L', Boldižárová K, Faix Š, Leng L', Kišidayová S 2005: The effects of organic selenium supplementation on the rumen ciliate population in sheep. Fol Microbiol 50: 353-356

Naziroglu M, Aksakal M, Cay M, Celik S 1997: Effect of vitamin E and selenium on some rumen parameters in lambs. Acta Vet Hung 45: 447-456

Ortman K, Pehrson B 1999: Effect of selenate as a feed supplement to dairy cows in comparison to selenite and selenium yeast. J Anim Sci 77: 3365-3370

Paglia DE, Valentine WN 1967: Studies on quantitative and qualitative characterization of erythrocyte glutathione peroxidase. J Lab Med 70: 158-169

Panev A, Hauptmanová K, Pavlata L, Pechová A, Filípek J, Dvořák R 2013: Effect of supplementation of various selenium forms and doses on selected parameters of ruminal fluid and blood in sheep. Czech J Anim Sci 58: $37-46$

Pappas AC, Zoidis E, Surai PF, Zervas G 2008: Selenoproteins and maternal nutrition. Comp Biochem Physiol B 151: $361-372$

Pavlata L, Illek J, Pechová A 2001: Blood and tissue selenium concentration in calves treated with inorganic or organic selenium compounds - a comparison. Acta Vet Brno 70: 19-26

Pavlata L, Mišurová L, Pechová A, Dvořák R 2011: The effect of inorganic and organically bound forms of selenium on glutathione peroxidase activity in the blood of goats. Vet Med 56: 75-81

Pavlata L, Slosarkova S, Fleische P, Pechová A 2005: Effects of increased iodine supply on the selenium status of kids Vet Med-Czech 50: 186-194

Pechova A, Ševčikova L, Pavlata L, Dvorak R 2012: The effect of various forms of selenium supplied to pregnant goats on selected blood parameters and on the concentration of Se in urine and blood of kids at the time of weaning. Vet Med 57: 394-403

Qin S, Gao J, Huang K 2007: Effects of different selenium sources on tissue selenium concentrations, blood GSH - Px activities and plasma interleukin levels in finishing lambs. Biol Trace Elem 116: 91-102

Rayman MP - 2004: The use of high-selenium yeast to raise selenium status: how does it measured up? Brit J Nutr 92: 557-573

Reitman S, Frankel S 1957: A colorimetric method for the determination of serum glutamic oxalacetic and glutamic pyruvic transaminases. Amer J Clin Pathol 28: 56-63 
Rock MJ, Kincaid RL, Carstens GE 2001: Effects of prenatal source and level of dietary selenium on passive immunity and thermometabolism of newborn lambs. Small Ruminant Res 40: 129-138

Rodriguez EM, Sanz MT, Romero CD 1994: Critical study of fluorometric determination of selenium in urine. Talanta 12: 2025-2031

Saini RK, Saini N, Kataria M, Babu S 2007: Effect of selenium and alpha-tocopherol on the antioxidant defense system of goat erythrocytes and the hemic system. Toxicol Mech Methods 17: 117-123

Serra AB, Nakamura K, Matsui T, Harumoto T, Fujihara T 1994: Inorganic selenium for sheep: II. Its influence on rumen microbial yield, volatile fatty acids production and total tract digestion of timothy hay. Asian-Australian J Anim Sci 7: 91-96

Shi LG, Xun WJ, Yue WB, Zhang CX, Ren YS, Liu Q, Wang Q, Shi L 2011: Effect of elemental nano-selenium on feed digestibility, rumen fermentation, and purine derivates in sheep. Anim Feed Sci Technol 163: 136-142

Schmidt E, Henkel E, Klauke R, Lorentz K, Sonntag O, Stein W, Weidemann G, Gerhardt W 1990: Proposal of standard routine methods for the determination of enzyme catalytic activity concentrations in serum and plasma at $37^{\circ} \mathrm{C}$. Fresenius J Anal Chem 337: 145-147

Schmidt E, Schmidt FW 1983: Glutamate dehydrogenase. In: Bergmeyer HK, Bergmeyer J, Grosse M (Eds): Methods of Enzymatic Analysis. $3^{\text {rd }}$ edn, Deer-field Beach, Fla, Verla-Chemie, pp. 216-227

Van Ryssen JB, Deagen JT, Beistein MA, Whanger PD 1989: Comparative metabolism of organic and inorganic selenium by sheep. J Agric Food Chem 37: 1358-1363

Van Ryssen JB, Schroeder GE 2003: Effect of heat processing of protein sources on the disappearance of their selenium from mobile bag in the digestive tract of dairy cows. Anim Feed Sci Technol 107: 15-27

Wang C, Liu Q, Yang WZ, Dong Q, Yang XM, He DC, Zhang P, Dong, KH, Huang, YX 2009: Effects of selenium yeast on rumen fermentation, lactation performance and feed digestibilities in lactating dairy cows. Live Sci 126: $239-244$

Xun W Shi, L Yue, W Zhang Ch, Ren Y, Liu Q 2012: Effect of high-dose nano-selenium and selenium-yeast on feed digestibility, rumen fermentation and purine derivates in sheep. Biol Trace Elem Res 150: 130-136 